\title{
Post-meiotic transcription in mouse testes detected with spermatid cDNA clones
}

\author{
Hirokazu FUJIMOTO*, Robert P. ERICKSON ${ }^{* *}$, Marie QUINTO, \\ and Michael P. ROSENBERG \\ Department of Human Genetics, Box 015 \\ University of Michigan School of Medicine, \\ 1137 E. Catherine Street, Ann Arbor, \\ Michigan, U.S.A. 48109-0010 \\ (Received 11 October 1984)
}

\begin{abstract}
cDNA clones to poly $(A)+$ mRNA from spermatids have been obtained to study gene transcription in postmeiotic germ cells. Four cDNA clones detect mRNAs that increase in abundance in post-meiotic germ cells. One clone, pPM459, was shown to correspond to an mRNA that is transcribed after meiosis. Pulse-labelling experiments demonstrate transcription of the message in spermatids. These data constitute further evidence for post-meiotic gene transcription in spermatids.
\end{abstract}

Non-Mendelian genetic transmission ratios, which occur in a variety of orgamisms, are most easily explained by post-meiotic gene transcription. In plants, where one male pronucleus is activated during pollen formation, the occurrence of distorted transmission ratios is common, e.g., the sugary locus in maize (1). Other well-studied examples of non-Mendelian transmission ratios include segregation Distorter in Drosophila (2) and t-alleles in mice (3,4). However, the syncytial nature of spermatogenesis has made it extremely difficult to prove post-meiotic gene transcription as a possible mechanism for non-Mendelian transmission. In recent years, the work of a number of investigators has provided evidence for mRNA synthesis after meiosis (5-11), but definitive evidence for post-meiotic transcription has awaited the availability of appropriate cDNA clones (12-14). We report here the isolation of four cDNA clones encoding spermatid poly $(A)+$ mRAs which increase in abundance after meiosis. Transcriptional studies further demonstrate that one cloned CDNA encodes a gene transcribed in post-meiotic germ cells.

*Current address: Mitsubishi-Kasei Institute of Life Sciences, 11 Minamiooya, Machida-shi, Tokyo 194, Japan.

**To whom reprint requests should be sent. 


\section{Materials and Methods}

\section{Cell fractionation}

Elutriation (centrifugation with a special cell-separation rotor) was performed on testicular germ cells from either adult testes or testes from 17-19-day-old CD-1 random-bred mice, which do not yet have post-meiotic cells, as previously described (7). Spermatids from irradiated $(300$ rads followed by two 100-rad treatments at 6-day intervals and killed $24 \mathrm{~h}$ following the third irradiation) CD-1 testes (7) were more than $90 \%$ pure.

\section{Cloning and screening spermatid mRNA}

mRNA was isolated from spermatids purified from irradiated mice by the Proteinase K-phenol method. Poly $(A)+$ RNA was purified on an oligo(dT)-cellulose column (7), from which single- and doublestranded cDNAs were synthesized (15) using avian myleblastosis virus reverse transcriptase (courtesy of J.W. Beard) and E. Coli DNA polymerase I (Bethesda Research Laboratories). The double-stranded CDNA was then digested with SI nuclease (Sigma), tailed with terminal transferase (P-L Biochemicals) in cobalt-cacodylate buffer and then purified on a Sephadex G-100 column (Pharmacia). dCMP-tailed double-stranded CDNA was then annealed to dG-tailed pBR322 (New England Nuclear). Clone pPM459 was prepared by annealing homopolymeric (dA)-tailed mRNA-cDNA hybrid molecules $(16,17)$ to homopolymeric (dT)-tailed Pst-1 cleaved pBR322. All recombinant DNA molecules were transformed into the $E$. coli DH-1 strain. Transformants were grown in the presence of tetracycline (20 $\mu \mathrm{g} / \mathrm{ml}$ ) and ampicillin sensitivity was detected by the rapid iodometric identification assay method (18). For colony hybridization, bacterial colonies were placed on nitrocellulose filters in duplicate and grown on tetracycline $(20 \mu \mathrm{g} / \mathrm{ml})$ agar plates, and then amplified with chloramphenicol $(170 \mu \mathrm{g} / \mathrm{ml})(19)$. The clones were lysed in situ (20) and hybridized with $2 \times 10^{6}$ c.p.m. of ${ }^{32}$-labeled cDNA synthesized from $\operatorname{poly}(A)+$ RNA.

\section{Cytosolic dot blots}

Cytosolic dot blots were prepared according to the method of White and Bancroft (21).

Transcriptional studies

Spermatids prepared by the elutriation (centrifugation) method were labellled in Dulbecco's minimal essential Eagle's medium, supplemented with $5 \%$ fetal calf serum, for $3 \mathrm{~h}$ at $32^{\circ} \mathrm{C}$ with the isotopes specified in the Table legends. They were then washed $3 x$ and lysed by addition of an equal volume of lysis buffer $14.8 \%$ SDS/0.2-M NaCl/15-mM EDTA/50-mM Tris, $\mathrm{pH} 7.5 / 200 \mu \mathrm{g} / \mathrm{ml}$ heparin sulfate). The RNA was extracted by the proteinase K-phenol/chloroform method. DNA was removed by an additional DNase I (6330 DPFF from Millipore) treatment using vanadyl ribonucleoside complex (BRL) as an RNase inhibitor (22). Isolated RNA was hybridized (34) to Genescreen II ${ }^{\circledR}$ (New England Nuclear) filters in $50 \%$ formamide, 
$2 \times$ SSC, $0.1 \%$ SDS, $10-\mathrm{mM}$ triethanolamine, $\mathrm{pH} 7.0$ for $24 \mathrm{~h}$ at $37^{\circ} \mathrm{C}$. Following the incubation, filters were washed in $2 x \mathrm{SSC}$ and treated with pancreatic ribonuclease I (Sigma), further washed in $2 x$ SSC and counted.

\section{Results}

Screening for clones containing abundant messages with increased signals in spermatid (post-meiotic) cells

E. Coli DH-1 cells were transformed with either double-stranded cDNA (clones 1-99) or mixed cDNA-mRNA hybrids (clone 459) cloned into the Pst 1 site of pBR322 by $d G-d C$ tailing respectively. This yielded 100 colonies with cloned inserts. These clones were initially screened in a colony hybridization assay to detect the clones representing mRNA synthesized preferentially in spermatids, thus, presumably transcribed post-meiotically. Duplicate nitrocellulose filters were prepared with the 100 recombinant clones and a pBR322 clone, and hybridized with ${ }^{32} \mathrm{P}$-labeled $\mathrm{CDNA}$ to poly $(\mathrm{A})^{+}$mRNA prepared from either spermatids or immature (18-19-day) testes (Fig. 1). Since immature testes have spermatogonia and spermatocytes, but no spermatids, they serve as a source of RNA synthesized in pre-meiotic cells. As shown in Fig. 1, four clones $(69,72,94$ [unnumbered in the Fig.], 459) yielded strong signals with the CDNA probe from spermatids, and weak or non-detectable signals with the cDNA probe from

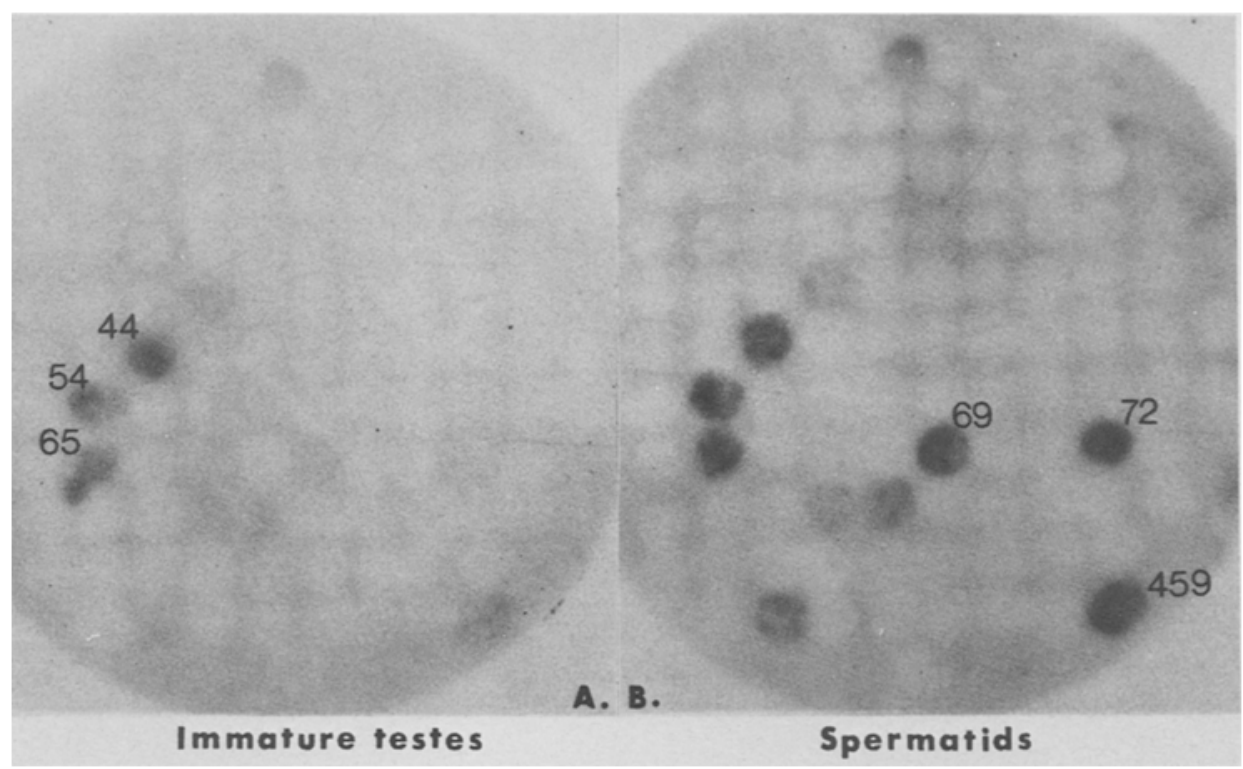

Fig. 1. Screening by filter colony hybridization for cDNA clones encoding spermatid poly(A) ${ }^{+}$mRNA. (A) Filter hybridized with $32 \mathrm{P}$-cDNA from immature (18-19-day-old) testicular poly(A) ${ }^{+}$RNA; and (B), filter hybridized with ${ }^{32} \mathrm{P}$-cDNA from poly(A) ${ }^{+}$RNA purified from spermatids isolated from irradiated mice. 


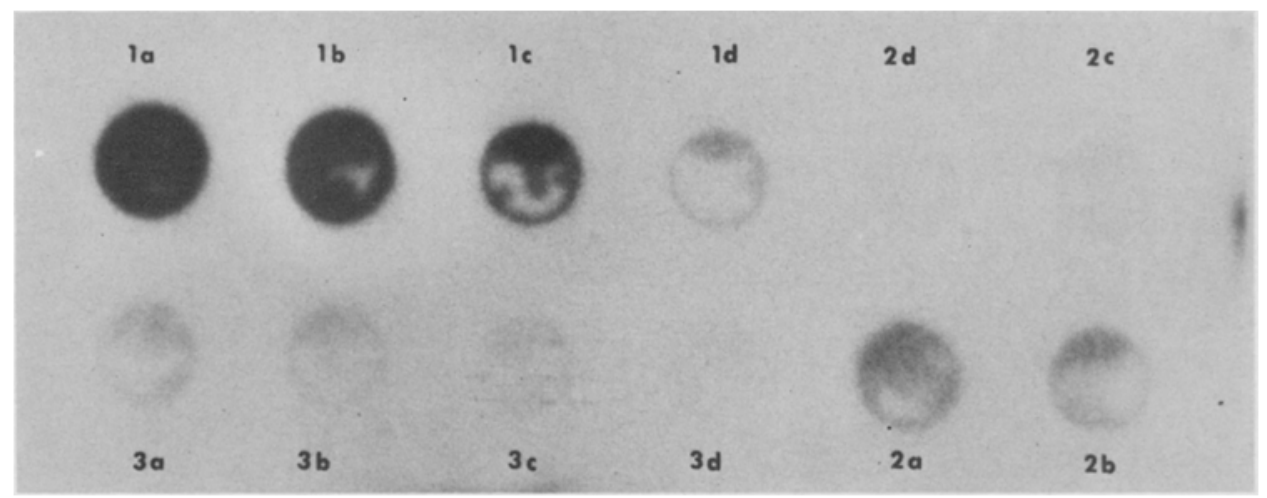

Fig. 2. Cytosolic dot hybridizations of testes from mice of different ages hybridized with pPM459. Samples corresponding to (a) 286 , (b) 143 , (c) 28.6 , and (d) $5.7 \mu \mathrm{g}$ of wet wt. of tissues were applied. 1a-d, day $21 ; 2 a-d$, day $14 ; 3 \mathbf{a - d}$, day 7 .

immature testes. Three colonies $(44,54,65)$ had a very strong signal with the spermatid probe; however, they were also found to have a much stronger signal than the other four when hybridized with the immature testicular cDNA probe. Because pPM459 (PM, post-meiotic) had the largest insert $(630 \quad 20)$, and because it gave clearer indications of being expressed post-meiotically in Northern blots, this clone was characterized in greater detail.

\section{Evidence for transcription of pPM459 in post-meiotic cells}

To demonstrate that messenger RNA corresponding to pPM459 is more abundant in post-meiotic germ cells, cytosolic dot hybridizations were performed using testes from mice of different developmental ages. The use of testes from immature mice to generate a developmental curve is based on the appearance of specific cell types during the onset of spermatogenesis in the testicular tubules. Thus, differential positive signals with pPM459 correlated with the appearance of specific cell types during spermatogenesis, and meiosis, in a developmental time course (Fig. 2). No signal, above that obtained with pBR322 alone (data not shown), was detected in cytosolic dots of day-7 neonatal testes. The testes at this stage have all the somatic elements, i.e., Leydig and Sertoli cells, as well as vascular and connective tissues present in adult gonads, thus demonstrating that pPM459 was not significantly expressed in these somatic cells. Spermatocytes first appear on day 13 in the testes. pPM459 hybridized to cytosolic dot blots from day-14 testes yielded a positive signal with 286 and $143 \mu \mathrm{g}$ of wet wt. testicular tissue. Finally, a strongly positive signal with pPM459 was detected in day-21 testes in as little as $5.7 \mu \mathrm{g}$ of wet wt. tissue. Early spermatids have made their appearance in the testes at about 20 days. Thus, we found approx. a 15-fold increase in the amount of pPM459 mRNA sequences when spermatids first appear in testes from 21-day-old mice compared to those from 14-day-old mice. 
Transcriptional assay for post-meiotic transcription of clone pPM459

Our data thus far have shown that pPM459-mRNA increases in abundance in spermatids. In order to determine if this tissue-specific regulation occurs at the transcriptional level, elutriator-purified spermatids were incubated in media containing $\left[5^{\prime}, 6^{\prime}-{ }^{3} \mathrm{H}\right]$ uridine for 3 $\mathrm{h}$ and then total RNA was isolated. Spermatid fractions that were at least $90 \%$ pure were used in these studies, with the major contaminant having been cytoplasmic fragments from late spermatids. We were able to obtain $190 \mu \mathrm{g}$ of RNA with a specific activity of $3.08 \times 10^{3}$ c.p.m./ug (Table 1). Although our level of incorporation was low, the amount of RNA we obtained was proportional to that obtained in previous isolations for an equivalent number of cells. The ${ }^{3} \mathrm{H}$-labeled RNA was then hybridized to filters containing $2.5 \mu \mathrm{g}$ of either ECO-RI-digested pPM459 or $f 7$ plasmid DNA. $f 7$ plasmid DNA (courtesy of $C$. Jahn) contains the cDNA of the B-globin major gene cloned into $\mathrm{pBR} 322$, and served as a negative control for subtraction of background. We were able to clearly detect a hybridized message to the filter containing pPM459 plasmid DNA when corrected against background, i.e., hybridization to $f 7$ filters.

Because total isolated spermatid RNA was used for hybridization, the values we obtained indicate that pPM459 mRNA only represents 246 parts per million, and therefore is of relatively low abundance (20\% of newly synthesized spermatid RNA contains poly(A) (5)). However, this was probably an underestimate of the amount actually present in spermatids.

We have also performed transcriptional studies using RNA labelled with adenine and uridine. Although cytoplasmic adenylation of pre-existing mRNA is described in fertilized eggs (23-25), mammalian somatic-cell mRNA adenylation is predominantly nuclear (26). There is little evidence of nuclear storage of transcripts and mammalian testicular nuclei turn over mRNA as rapidly as, if not more rapidly than, somatic nuclei (27). Thus, the double-labelled RNA most likely reflects newly synthesized and polyadenylated RNA. Using the double label, although the specific activity of RNA was lower, we found a

Table 1. Hybridization of $\left[{ }^{3} \mathrm{H}\right]$ uridine-labeled spermatid RNA to pPM459

$1.1 \times 10^{8}$ spermatids were incubated in $500 \mu \mathrm{Ci}$ of $\left[5^{\prime}, 6^{\prime}-\right.$ $3_{\mathrm{H}}$ ]uridine $(42 \mathrm{Ci} / \mathrm{mmol})$ in $10 \mathrm{ml}$ of Dulbecco's minimal essential medium with $5 \%$ heat-inactivated fetal calf serum for $3 \mathrm{~h}$ at $32^{\circ} \mathrm{C}$. The isolated RNA had a specific activity of $3.08 \times 10^{3} \mathrm{c} . \mathrm{p} . \mathrm{m} . / \mathrm{\mu g}$; $23.75 \mu \mathrm{g}$ of RNA $\left(73.25 \times 10^{3}\right.$ c.p.m.) was hybridized to filters containing $2.5 \mathrm{\mu g}$ of ECo-RI-digested pPM459 and $\mathrm{f7}$ (mouse major B-globin probe in pBR322, negative control) plasmid DNAs.

\begin{tabular}{|c|c|c|c|}
\hline Plasmid & C.p.m./filter* & C.p.m. - control & P.p.m. hybridized \\
\hline f 7 & $4.35 \pm 1.50$ & - & - \\
\hline pPM459 & $22.37 \pm 0.33$ & 18.02 & 246 \\
\hline
\end{tabular}

* Mean \pm standard error. 
nearly 10 -fold greater hybridization signal when PBR322 alone was used as the control, but a 5-fold greater hybridization signal when ${ }^{32} \mathrm{P}$ labelled pBR322 was used as an internal control (Table 2) for the expected variability in amounts of DNA on filters.

\section{Discussion}

Autoradiographic studies of early mouse spermatids were originally interpreted as showing little RNA synthesis (28). Quantitative autoradiographic analyses showed, however, that the rate of RNA synthesis per cell decreased only four-fold during meiosis, i.e., the RNA-synthesis-to-DNA ratio was essentially unchanged across the meiotic divisions (11). Such studies depend upon the incorporation of exogenous $\left[{ }^{3} \mathrm{H}\right]$ uridine into RNA. If the intracellular uridine pool size was greatly decreased in post-meiotic cells, added $\left[{ }^{3} \mathrm{H}\right]$ uridine would be more quickly taken up into the pool. Consequently the label would be incorporated into RNA more rapidly, inflating the apparent rate of RNA synthesis. However, pool-size estimates indicate that the intracellular uridine pool is increasing, rather than decreasing, after meiosis (29), thus resulting in a tendency to underestimate total RNA synthesis. With this consideration in mind, and considering the fact that total RNA was hybridized to the filters, our estimates of the amount of pPM459 mRNA transcribed may be artificially low.

Table 2. Hybridization of $\left[{ }^{3} \mathrm{H}\right]$ uridine- and $\left[{ }^{3} \mathrm{H}\right]$ adenine-

labelled spermatid RNA to pPM459

$3.7 \times 10^{8}$ spermatids were labelled with $800 \mu \mathrm{Ci}$ of $\left[5^{\prime}, 6^{\prime}-3^{3}\right]$ uridine (42 $\mathrm{Ci} / \mathrm{mmol}$ ) and $800 \mu \mathrm{Ci}$ of $\left[2,8-3_{\mathrm{H}}\right]$ adenosine (3I $\mathrm{Ci} / \mathrm{mmol}$ ) in $12 \mathrm{ml}$ of media. The resultant RNA had a specific activity of $1.42 \times 10^{3} \mathrm{c} \cdot \mathrm{p} \cdot \mathrm{m} . / \mathrm{\mu g}$.

\begin{tabular}{|c|c|c|c|c|c|}
\hline & & Plasmid & C.p.m./filter ${ }^{*}$ & C.p.m. - background & $\%$ Hybridized \\
\hline & Without internal & pBR322 & $2671 \pm 86$ & - & - \\
\hline & & PPM459 & $3524 \pm 213$ & 853 & 0.284 \\
\hline & & Plasmid & ${ }^{3} \mathrm{H}-c \cdot p \cdot m$. & $\begin{array}{c}\text { \% Hybridization } \\
\text { corrected for } \\
\text { pBR322** }\end{array}$ & $\%$ Hybridized \\
\hline \multirow[t]{2}{*}{ b) } & With internal & pBR322 & $1149.5 \pm 22.2$ & 0.134 & \\
\hline & & pPM459 & $312.6 \pm 39.6$ & 0.284 & 0.15 \\
\hline
\end{tabular}

* Mean \pm standard error.

$* * \frac{\left[{ }^{3} \text { H }\right] \text { RNA hybridized }}{\left[{ }^{3} \text { H RNA input }\right.} \times \frac{\left[{ }^{32} \mathrm{P}\right] \text { pBR322 maximum bound }}{\left[{ }^{32} \mathrm{P}\right] \mathrm{pBR} 322 \text { hybridized }}$

$+212.5 \mu \mathrm{g}$ of total RNA containing $300.8 \times 10^{3}$ c.p.m. was hybridized to $2.5 \mu g$ of plasmid DNA.

${ }^{7} 80.2 \mu \mathrm{g}$ of total RNA containing $113.5 \times 10^{3}$ c.p.m. and $0.25 \mathrm{ng}$ of ${ }^{32} \mathrm{P}-$ pBR322 was hybridized to $2.5 \mathrm{\mu g}$ of plasmid DNA. 
The data we have obtained with cytosolic dot blots, colony hybridization, and a transcriptional assay are compatible with postmeiotic expression of a gene containing homology to pPM459. Interestingly, all four clones we have obtained are expressed to a minor extent in spermatocytes, but their corresponding message is more abundant in spermatids. Recently, Kleene et al. (12) have found that 17 cDNA clones from testicular poly $(A)^{+}$RNA preferentially hybridized to spermatid RNA, while Dudley et al. (14) found that the messages detected by 6 out of 10 testes-specific cDNA clones studied showed increased abundance after meiosis. The message for a sperm-specific tubulin has also only been found in post-meiotic cells (13). However, mRNA for Pgk-2 first appears during meiosis, where it appears in a non-polysomal fraction, and increases in amount in round spermatids where it is found in the polysomal fraction (19). These workers have suggested that $P g k-2$ mRNA may be stored in the form of an inactive mRNP, and that its accumulation in spermatids is consistent with post-meiotic gene expression. Enrichment of mRNA by the selective degradation of other mRNAs would not be an adequate explanation for both our results and the results obtained by others (12-14) since the amount of mRNA per amount of DNA decreases about $30 \%(30)$ in early spermatids. Also, our cloning screening methods would select for highly abundant spermatid mRNA. Therefore, our data and that of others (12-14) are more compatible with transcription after meiosis.

\section{Acknowledgements}

Initial cloning experiments were carried out in the the P1 facilities of Dr. Richard Tashian's laboratory. We thank Pat Venta for useful suggestions and for gifts of $\mathrm{DH}-1$ and pBR322, Ken Harper for technical assistance, and Rena Jones for excellent secretarial help. H. F. was on leave from the Laboratory of Cell Biology, Mitsubishi-Kasei Institute of Life Sciences, Tokyo, Japan. The work was supported by grant HD 11738 from the National Institutes of Health.

\section{References}

1. Brink R \& Burnham CR (1927) Genetics 12, 348-378.

2. Zimmering S, Sandler L \& Nicoletti B (1970) Ann. Rev. Genet. 4, 409-436.

3. Gluecksohn-Waelsch S \& Erickson RP (1970) Current Topics Develop. Biol. 5, 281-316.

4. Bennett D (1975) Ce11 6, 441-454.

5. Erickson RP, Erickson JM, Betlach CJ \& Meistrich ML (1980) J. Exp. Zoo1. 214, 13-19.

6. Erickson RP, Kramer J, Rittenhouse J \& Salkeld A (1980) Proc. Natl. Acad. Sci. U.S.A. 77, 6086-6090.

7. Fujimoto H \& Erickson RP (1982) Biochem. Biophys. Res. Commun. 108, $1369-1375$.

8. Geremia R, D'Agostino A\& Monesi V (1978) Exp. Cel1 Res. 111, 23-30.

9. Gold B, Fujimoto H, Kramer JM, Erickson RP \& Hecht NB (1983) Develop. Biol. 98, 392-399. 
10. Kierzenbaum AL \& Tres LL (1975) J. Cel1 Biol. 65, 258-270.

11. Loir M (1972) Ann. Biol. Anim. Biochim. Biophys. 12, 203-219.

12. Kleene KC, Distel RJ \& Hecht NB (1983) Develop. Biol. 98, 455-464.

13. Distel RJ, Kleene KC \& Hecht NB (1984) Science 224, 68-70.

14. Dudley K, Potter J, Lyon MF \& Willison KR (1984) Nucleic Acid Res. 12, 4281-4293.

15. Wickens MP, Buell GN \& Schimke RT (1978) J. Biol. Chem. 253, 2483-2495.

16. Krueger LJ, Krauss MR, Caryk TM \& Anderson WF (1978) Biochem. Biophys. Res. Comm. 82, 60-66.

17. Zain S, Sambrook J, Roberts RJ, Keller W, Fried M \& Dunn AR (1979) Cel1 16, 851-861.

18. Boyko wL \& Ganschow RE (1982) Anal. Biochem. 122, 85-88.

19. Hanahan D \& Meselson M (1980) Gene 10,63-67.

20. Thayer RE (1979) Anal. Biochem. 98, 60-63.

21. White BA \& Bancroft FC (1982) J. Biol. Chem. 257, 8569-8572.

22. Maniatis T, Fritsch EF \& Sambrook J (1982) Molecular Cloning: A Laboratory Manual, p. 192, Cold Spring Harbor, New York, U.S.A.

23. Clegg KB \& Piko L (1983) Nature 295, 342-345.

24. Slater I, Gillespie D \& Slater DW (1973) Proc. Natl. Acad. Sci. U.S.A. 70, 406-411.

25. Wilt FH (1973) Proc. Nat1. Acad. Sci. U.S.A. 70, 2345-2349.

26. Brawerman G \& Diez J (1975) Cel1 5, 271-280.

27. Muramatsu M, Utakoji T \& Sugano H (1968) Exp. Cel1 Res. 53, 278-283.

28. Monesi V (1967) Arch. Anat: Microscop. Morphol. Exp. 56, 61-74.

29. Geremia R, Boitani C, Conti M \& Monesi V (1977) Cel1 Differen. $5,343-355$.

30. Gold B, Stern L, Bradley FM \& Hecht NB (1983) J. Exp. Zool. $225,125-134$. 